\title{
Cardiorespiratory Fitness and Fatness Are Associated With Health Complaints and Health Risk Behaviors in Youth
}

\author{
José Castro-Piñero, Carmen Padilla-Moledo, Francisco B. Ortega, \\ Diego Moliner-Urdiales, Xiaofen Keating, and Jonatan R. Ruiz
}

\begin{abstract}
Background: We examined the association of cardiorespiratory fitness and fatness with health complaints and health risk behaviors in 691 (323 girls) Spanish children aged 6 to 17.9. Methods: Health complaints and health risk behaviors were self-reported using items of the Health Behavior in School-aged Children questionnaire. Weight and height were measured and body mass index was computed. Cardiorespiratory fitness was measured by the 20-m shuttle-run test, and youth categorized as fit/unfit. Results: Unfit youth were more likely to report health complaints sometime (OR: 2.556, 95\% CI: 1.299-5.031; and OR: 1.997, 95\% CI: 1.162-3.433, respectively) and health risk behaviors such as drinking alcohol sometime (OR: 5.142, 95\% CI: 1.214-21.783; and OR: 2.413, 95\% CI: 1.484-3.923) than their fit counterparts. Overweight-obese youth were more likely to report health complaints (OR: 1.732, 95\% CI: 1.019-2.945; and OR: 1.983, 95\% CI: 1.083-3.629, respectively). The analysis of the combined influence of fitness and fatness revealed that fit youth had lower health complaints index than the fat-unfit and unfat-unfit groups (all $P<.05$ ). Conclusions: Low fitness and overweight-obesity increased the risk of having health complaints in youth, yet high levels of cardiorespiratory fitness might overcome deleterious effects of overweight-obesity on health complaints.
\end{abstract}

Keywords: aerobic capacity, obesity, alcohol and tobacco, children, adolescents

Health complaints refer to somatic and psychological symptoms experienced by the individual with or without a defined diagnosis such as abdominal pain, headache, backache, nervousness, and sleeping difficulties. It constitutes a diverse set of symptoms where few are related to a defined diagnosis or disease. ${ }^{1}$ Such symptoms constitute both everyday experiences and health problems, and are common causes of disability and sickness certificates in adults. ${ }^{2}$ In youth, previous studies showed weekly health complaints, which likely influences on wellbeing and functional ability. ${ }^{3}$ Health complaints has also been considered as a negative outcome of the developmental processes. ${ }^{3}$

Health risk behaviors, especially smoking and drinking, are one of the major health concerns among west countries. Both are associated with the leading causes of mortality and morbidity, posing immediate risks to

Castro-Piñero and Padilla-Moledo are with the Dept of Physical Education, University of Cadiz, Puerto Real, Spain. CastroPiñero is also with the Dept of Biosciences and Nutrition, Karolinska Institute, Huddinge, Sweden. Ortega and Ruiz are with the Dept of Biosciences and Nutrition at NOVUM, Unit for Preventive Nutrition, Karolinska Institute, Huddinge, Sweden. Ortega and Ruiz are also with the Dept of Physical Education, School of Sport Sciences, University of Granada, Granada (Spain). Moliner-Urdiales is with the Dept of Education, University Jaume I, Castellón, Spain. Keating is with the Dept of Curriculum and Instruction, University of Texas, Austin, TX. health during adolescence and increasing the likelihood of excess preventable morbidity and death in adulthood. ${ }^{4,5}$

Findings from cross-sectional and longitudinal studies showed that high cardiorespiratory fitness is associated with a healthier cardiovascular profile in youth. ${ }^{6-8}$ Less is known however whether cardiorespiratory fitness is associated with health complaints ${ }^{9,10}$ and health risk factors in youth. ${ }^{11-13}$ On the other way, physical activity is inversely related with health complaints ${ }^{14,15}$ and health risk behaviors such as smoking. ${ }^{14-16}$

Studies examining the association of fatness with health complaints and health risk factors in youth are scarce and the results contradictory. ${ }^{17-20}$ The findings so far showed that overweight adolescents are more likely to describe themselves as having health problems compared with their nonoverweight peers. ${ }^{21-23}$ Moreover, previous studies suggest that compromising behaviors such as overweigh/obesity, smoking or drinking may co-occur during adolescence. ${ }^{24-28}$

The aim of the current study was to examine the association of cardiorespiratory fitness and fatness with health complaints and health risk behaviors in Spanish youth.

\section{Methods}

\section{Subjects}

A sample of 691 (368 boys and 323 girls) healthy Caucasian children (mean age \pm standard deviation: $9.3 \pm$ 
1.6 years; $6-11.9$ years $)$ and adolescents $(14.8 \pm 1.9$ years; $12-17.9$ years) participated in the study. Data collection took place from February to June 2006. The sample was randomly selected using a 2-phase, proportional cluster sampling using as a reference the database of the census of the province of Cádiz (South Spain), to establish a representative sample of the area. In the first phase, the school was selected from the stratum according to the geographical localization, by age and sex. A total of 9 urban and 9 rural governmental schools agreed to participate in the study. In the second phase, classes (at least 50\% per level) from schools were randomly selected and used as the smallest sampling units. All the pupils of the selected classroom were invited to participate in the study. The participation was higher than $95 \%$.

A comprehensive verbal description of the nature and purpose of the study was given to the children, adolescents, their parents and teachers. This information was also sent to parents or youth' supervisors by regular e-mail, and written consents from parents, children and adolescents were requested. The study was approved by the Review Committee for Research Involving Human Subjects at the University of Cádiz, Spain.

\section{Measures}

Health complaints and health risk behaviors (tobacco and alcohol use, and drunk) were assessed by the Health Behavior in School-aged Children (HBSC) questionnaire. ${ }^{29,30}$ Participants completed the questionnaire in school classroom with trained investigators. All the questions used in the HBSC questionnaire showed a good reliability and validity in youth. . $^{31,32}$

Health Complaints. Participants indicated how frequently [5-point scale: rarely or never (1), almost every month (2), almost every week (3), more than once a week (4), and almost every day (5)] they had each of the following symptoms: headache, stomach-ache, backache, feeling low, irritability or bad temper, feeling nervous, difficulties getting to sleep, feeling dizzy. A mean of the responses represented subjective health complaints index. ${ }^{14}$ The index was dichotomized as never (rarely or never) or sometime (almost every month, almost every week, more than once a week, and almost every day). The internal consistency of the items of the health complaints index was acceptable (Cronbach's alpha $=.714)$.

Tobacco Use. We used a single item to assess cigarette smoking: "How often do you smoke tobacco at present?" Possible answers were I do not smoke (1), less than once a week (2), at least once a week but not every day (3), and every day (4). The responses were dichotomized as never (I do not smoke) or sometime (less than once a week, at least once a week but not every day, and every day).

Alcohol Use. Participants indicated how frequently [converted to days/week: never (0), rarely (.1), every month (.25), every week (1), and every day (7)] they drunk each of 3 beverages (beer, wine, combined liquors). A mean of the responses represented alcohol use. ${ }^{14}$ The responses were dichotomized as never (never), and sometime (rarely, every month, every week, and every day). The internal consistency of the items of alcohol use was high $($ Cronbach's alpha $=.937)$.

Drunk. A single item, asking "Have you ever got drunk any time?" [5-point scale: never (0), once (1), 2 to 3 times (2), 4 to 10 times (3), and more than 10 times (4)], indicated how frequently they get drunk. The responses were dichotomized as never (never) or sometime (once, 2 to 3 times, 4 to 10 times, and more than 10 times).

Cardiorespiratory Fitness. Cardiorespiratory fitness was assessed by means of the $20-\mathrm{m}$ shuttle run test as described by Léger et al. ${ }^{33}$ In brief, participants were required to run between 2 lines $20 \mathrm{~m}$ apart, while keeping the pace with audio signals emitted from a prerecorded compact disk (CD). The initial speed was $8.5 \mathrm{~km} / \mathrm{h}$, which was increased by $0.5 \mathrm{~km} / \mathrm{h}$ per minute (1 minute equals 1 stage). The CD used was calibrated over 1 minute of duration. Participants were instructed to run in a straight line, to pivot on completing a shuttle, and to pace themselves in accordance with the audio signals. The participants were encouraged to keep running as long as possible throughout the course of the test. The test was finished when the participant failed to reach the end lines concurrent with the audio signals on 2 consecutive occasions. Otherwise, the test ended when the subject stopped because of fatigue. All measurements were carried out under standardized conditions on an indoor rubber floored gymnasium. The last stage completed was scored (precision of 0.5 steps).

Participants were classified in low and high cardiorespiratory fitness level according to the FITNESSGRAM standards for Healthy Fitness Zone. ${ }^{34}$ All participants received a comprehensive instruction of the test after which they also practiced it. They were instructed to abstain from strenuous exercises 48 hours before the test.

Body Fatness. Height and weight were measured with physical education clothing (shorts and t-shirt) and with barefoot. Height was measured to the nearest $0.1 \mathrm{~cm}$ using stadiometer (Holtain Ltd, Crymmych, Pembs, United Kingdom). Weight was measured to the nearest $0.1 \mathrm{~kg}$ using a Seca scale (Seca, Hamburg, Germany). Instruments were calibrated to ensure the acceptable accuracy. Body mass index (BMI) was calculated as weight/height squared $\left(\mathrm{kg} / \mathrm{m}^{2}\right)$. Participants were categorized according to the BMI international cut-off values as nonoverweight and overweight plus obese. ${ }^{35}$

Body fat percentage was calculated by the equations reported by Slaughter et al using triceps and calf skinfolds. ${ }^{36}$ Skinfolds were measured to the nearest 0.1 with a skinfold caliper (Slim guide Tom Kit Rosscraft1, Canada). Triceps skinfold was measured on the right side of the body at the following site: a vertical fold halfway between the acromion process and the superior head of the radius, in the posterior aspect of the arm. Calf skinfold 
was measured on the inside of the right leg at the level of maximal calf girth. The right foot was placed flat on an elevated surface with the knee flexed at a $90^{\circ}$ angle. The vertical skinfold should be grasped just above the level of maximal girth and the measurement made below the grasp.

Participants were categorized in low and high body fat percentage, according to the FITNESSGRAM standards for Healthy Fitness Zone. ${ }^{34}$

BMI and skinfold thickness were used as indicators of body fat because of 1) the results on the association between positive health and obesity in children and adolescents is inconclusive,$^{37-40}$ which might be due to the fact that the adiposity indicator used varies among studies; 2) to make our data comparable with other studies using mainly BMI; and 3) because it could be argue that BMI is not a valid indicator of body fat in children and adolescents, ${ }^{41}$ and it could be also argue that skinfold thickness is not a valid indicator of body fat in obese children and adolescents (due to the fact that the measurement error increases in these individuals). ${ }^{41}$

\section{Statistical Analysis}

Data are presented as mean and standard deviation, unless otherwise indicated. Analyses were performed using the PASW (v. 18.0 for WINDOWS, Chicago), and the level of significance was set to 0.05 .

We compared health complaints index and health risk behaviors between children and adolescents using the Mann-Whitney $U$ test. The association of fitness and fatness with health complaints index and health risk factors was examined using regression analysis. Further, we performed binary logistic regression analysis to examine the association of low fitness and overweight-obesity with health complaints and health risk behaviors. Since there were no sex*health complaints index or sex*health risk behaviors interactions with cardiorespiratory fitness and fatness, all the analyses were performed jointly for boys and girls and the models adjusted for sex. Skewed distributions for health complaints, tobacco use and the 2 alcohol questions were modified using log transformations; however to simplify the interpretation, the means shown in Table 1 are before transformation.
Finally, we examined the combined effects of cardiorespiratory fitness and fatness (based on BMI cut-off points) on health complaints index using 1-way analysis of covariance after adjusting for age and sex. For this analysis, we created 4 fat-fit combination categories: 1) fat and unfit (overweight+obese and low fitness); 2) fat and fit (overweight+obese and high fitness); 3) unfat and unfit (nonoverweight and low fitness); and 4) unfat and fit (nonoverweight and high fitness). Pair group comparisons were performed with Bonferroni test. We repeated the analyses further adjusting for school and the results did not change (data not shown).

\section{Results}

Adolescents had significantly higher values of health complaints index and health risk behaviors than children (Table 1).

Cardiorespiratory fitness was inversely associated with health complaints index in children and adolescents, and inversely associated with tobacco use only in children (Table 2). BMI was positively associated with health complaints index in both children and adolescents, whereas it was positively associated with alcohol use only in children. Similar results were observed when body fatness was expressed as body fat percentage.

Children and adolescents with low cardiorespiratory fitness had significantly higher odds ratio (OR) of having health complaints and drinking alcohol sometime (Table 3). Likewise, adolescents with low cardiorespiratory fitness had significantly higher OR of getting drunk sometime. Overweight-obese children and those with high body fat percentage had higher OR of having health complaints sometime.

The association between health complaints index and fat-fit categories is presented in Figure 1. Children and adolescents who were fit had lower health complaints index than their unfit counterparts, independently of their weight status. Furthermore, the multinomial logistic regression analysis indicated that fat-unfit and unfatunfit youth were more likely to report health complaints sometime (OR: 2.593, 95\% CI: 1.458-4.610; and OR: 2.654, 95\% CI: $1.586-4.458$, respectively) compared with the unfat-fit group (reference group). We repeated the analyses using body fat groups according to the

Table 1 Mean (M) and Standard Deviation (SD) for Health Complaints Index and Health Risk Behaviors by Age Group

\begin{tabular}{lcccccc}
\hline & \multicolumn{2}{c}{ Children (6-11.9 y) } & & \multicolumn{2}{c}{ Adolescents (12-17 y) } \\
\cline { 1 - 2 } \cline { 5 - 6 } & $\mathbf{N}$ & & Mean \pm SD & & N & Mean \pm SD \\
\hline Health complaints index (1-5) & 365 & $1.570 \pm 0.588$ & & 300 & $1.761 \pm 0.610$ \\
Tobacco use (1-4) & 381 & $1.000 \pm 0.051$ & & 306 & $1.242 \pm 0.772$ \\
Alcohol use (days/week) & 385 & & $0.019 \pm 0.359$ & & 303 & $0.080 \pm 0.159$ \\
Drunk (0-4) & 383 & $0.020 \pm 0.250$ & & 306 & $0.480 \pm 0.996$ \\
\hline
\end{tabular}

Note. All $P<.001$ age group differences. 
Table 2 Standardized Regression Coefficients $(\beta)$ Showing the Association of Cardiorespiratory Fitness (Expressed as $\mathrm{ml} / \mathrm{kg} / \mathrm{min}$ ), Body Mass Index $\left(\mathrm{kg} / \mathrm{m}^{2}\right)$, and Body Fat Percentage With Negative Health Indicators in Children and Adolescents

\begin{tabular}{|c|c|c|c|c|c|c|}
\hline & \multicolumn{3}{|c|}{ Children (6-11.9 y) } & \multicolumn{3}{|c|}{ Adolescents (12-17 y) } \\
\hline & $\mathbf{N}$ & $\boldsymbol{\beta}$ & $\boldsymbol{P}$ & $\mathbf{N}$ & $\boldsymbol{\beta}$ & $\boldsymbol{P}$ \\
\hline \multicolumn{7}{|l|}{ Cardiorespiratory fitness } \\
\hline Health complaints index & 354 & -0.149 & 0.005 & 285 & -0.176 & 0.002 \\
\hline Tobacco use & 370 & -0.066 & 0.202 & 291 & -0.108 & 0.048 \\
\hline Alcohol use & 369 & -0.037 & 0.469 & 288 & -0.078 & 0.152 \\
\hline Drunk & 372 & 0.039 & 0.449 & 291 & -0.080 & 0.144 \\
\hline \multicolumn{7}{|l|}{ Body mass index } \\
\hline Health complaints index & 354 & 0.108 & 0.044 & 290 & 0.128 & 0.029 \\
\hline Tobacco use & 369 & -0.018 & 0.726 & 296 & 0.006 & 0.915 \\
\hline Alcohol use & 369 & 0.118 & 0.024 & 293 & 0.073 & 0.202 \\
\hline Drunk & 371 & -0.014 & 0.794 & 296 & 0.068 & 0.234 \\
\hline \multicolumn{7}{|l|}{ Body fat percentage } \\
\hline Health complaints index & 353 & 0.113 & 0.033 & 288 & 0.054 & 0.501 \\
\hline Tobacco use & 368 & -0.031 & 0.555 & 294 & 0.021 & 0.715 \\
\hline Alcohol use & 367 & 0.112 & 0.032 & 291 & -0.049 & 0.388 \\
\hline Drunk & 370 & 0.027 & 0.601 & 294 & -0.088 & 0.119 \\
\hline
\end{tabular}

Note. All analyses were controlled for sex.

Table 3 Association of Low Cardiorespiratory Fitness Level, Being Overweight and Obese, and Having a High Body Fat Percentage (FITNESSGRAM Standards for Healthy Fitness Zone) With Negative Health Indices in Children and Adolescents

\begin{tabular}{|c|c|c|c|c|c|c|c|}
\hline & & \multicolumn{3}{|c|}{ Children (6-11.9 years) } & \multicolumn{3}{|c|}{ Adolescents (12-17 years) } \\
\hline & & $\mathrm{N}$ & OR & $95 \% \mathrm{Cl}$ & $\mathbf{N}$ & OR & $95 \% \mathrm{Cl}$ \\
\hline \multicolumn{8}{|l|}{ Cardiorespiratory fitness } \\
\hline Health complaints index & $\begin{array}{l}\text { Never } \\
\text { Sometime }\end{array}$ & $\begin{array}{c}303 \\
51\end{array}$ & $\begin{array}{c}1 \\
\mathbf{2 . 5 5 6}\end{array}$ & $\begin{array}{c}\text { Referent } \\
\mathbf{1 . 2 9 9 - 5 . 0 3 1}\end{array}$ & $\begin{array}{l}173 \\
112\end{array}$ & $\begin{array}{c}1 \\
\mathbf{1 . 9 9 7}\end{array}$ & $\begin{array}{c}\text { Referent } \\
\mathbf{1 . 1 6 2 - 3 . 4 3 3}\end{array}$ \\
\hline Tobacco use & $\begin{array}{l}\text { Never } \\
\text { Sometime }\end{array}$ & $\begin{array}{c}318 \\
52\end{array}$ & $\begin{array}{l}1 \\
-\end{array}$ & $\begin{array}{c}\text { Referent } \\
-\end{array}$ & $\begin{array}{l}177 \\
114\end{array}$ & $\begin{array}{c}1 \\
1.720\end{array}$ & $\begin{array}{c}\text { Referent } \\
0.782-3.783\end{array}$ \\
\hline Alcohol use & $\begin{array}{l}\text { Never } \\
\text { Sometime }\end{array}$ & $\begin{array}{c}318 \\
51\end{array}$ & $\begin{array}{c}1 \\
\mathbf{5 . 1 4 2}\end{array}$ & $\begin{array}{c}\text { Referent } \\
\mathbf{1 . 2 1 4 - 2 1 . 7 8 3}\end{array}$ & $\begin{array}{l}175 \\
113\end{array}$ & $\begin{array}{c}1 \\
\mathbf{2 . 4 1 3}\end{array}$ & $\begin{array}{c}\text { Referent } \\
\mathbf{1 . 4 8 4 - 3 . 9 2 3}\end{array}$ \\
\hline Drunk & $\begin{array}{l}\text { Never } \\
\text { Sometime }\end{array}$ & $\begin{array}{c}320 \\
52\end{array}$ & $\begin{array}{l}1 \\
-\end{array}$ & $\begin{array}{c}\text { Referent } \\
-\end{array}$ & $\begin{array}{l}177 \\
114\end{array}$ & $\begin{array}{c}1 \\
1.952\end{array}$ & $\begin{array}{c}\text { Referent } \\
\mathbf{1 . 1 3 7 - 3 . 3 5 1}\end{array}$ \\
\hline \multicolumn{8}{|l|}{ Overweight/Obese } \\
\hline Health complaints index & $\begin{array}{l}\text { Never } \\
\text { Sometime }\end{array}$ & $\begin{array}{l}250 \\
104\end{array}$ & $\begin{array}{c}1 \\
\mathbf{1 . 7 3 2}\end{array}$ & $\begin{array}{c}\text { Referent } \\
\mathbf{1 . 0 1 9 - 2 . 9 4 5}\end{array}$ & $\begin{array}{c}218 \\
72\end{array}$ & $\begin{array}{c}1 \\
1.218\end{array}$ & $\begin{array}{c}\text { Referent } \\
0.664-2.236\end{array}$ \\
\hline Tobacco use & $\begin{array}{l}\text { Never } \\
\text { Sometime }\end{array}$ & $\begin{array}{l}261 \\
108\end{array}$ & $\begin{array}{l}1 \\
-\end{array}$ & $\begin{array}{c}\text { Referent } \\
-\end{array}$ & $\begin{array}{c}223 \\
73\end{array}$ & $\begin{array}{c}1 \\
0.661\end{array}$ & $\begin{array}{c}\text { Referent } \\
0.240-1823\end{array}$ \\
\hline Alcohol use & $\begin{array}{l}\text { Never } \\
\text { Sometime }\end{array}$ & $\begin{array}{l}262 \\
107\end{array}$ & $\begin{array}{c}1 \\
3.247\end{array}$ & $\begin{array}{c}\text { Referent } \\
0.857-12.370\end{array}$ & $\begin{array}{c}220 \\
73\end{array}$ & $\begin{array}{c}1 \\
1.409\end{array}$ & $\begin{array}{c}\text { Referent } \\
0.821-2.418\end{array}$ \\
\hline Drunk & $\begin{array}{l}\text { Never } \\
\text { Sometime }\end{array}$ & $\begin{array}{l}262 \\
109\end{array}$ & $\begin{array}{c}1 \\
1.160\end{array}$ & $\begin{array}{c}\text { Referent } \\
0.104-12.978\end{array}$ & $\begin{array}{c}223 \\
73\end{array}$ & $\begin{array}{c}1 \\
1.054\end{array}$ & $\begin{array}{c}\text { Referent } \\
0.565-1.968\end{array}$ \\
\hline \multicolumn{8}{|l|}{ Body fat percentage } \\
\hline Health complaints index & $\begin{array}{l}\text { Never } \\
\text { Sometime }\end{array}$ & $\begin{array}{c}280 \\
73\end{array}$ & $\begin{array}{c}1 \\
1.983\end{array}$ & $\begin{array}{c}\text { Referent } \\
\mathbf{1 . 0 8 3 - 3 . 6 2 9}\end{array}$ & $\begin{array}{c}238 \\
50\end{array}$ & $\begin{array}{c}1 \\
1.224\end{array}$ & $\begin{array}{c}\text { Referent } \\
0.605-2.477\end{array}$ \\
\hline Tobacco use & $\begin{array}{l}\text { Never } \\
\text { Sometime }\end{array}$ & $\begin{array}{c}290 \\
78\end{array}$ & $\begin{array}{l}1 \\
-\end{array}$ & $\begin{array}{c}\text { Referent } \\
-\end{array}$ & $\begin{array}{c}242 \\
52\end{array}$ & $\begin{array}{c}1 \\
0.813\end{array}$ & $\begin{array}{c}\text { Referent } \\
0.266-2.486\end{array}$ \\
\hline Alcohol use & $\begin{array}{l}\text { Never } \\
\text { Sometime }\end{array}$ & $\begin{array}{c}290 \\
77\end{array}$ & $\begin{array}{c}1 \\
1.725\end{array}$ & $\begin{array}{c}\text { Referent } \\
0.405-7.348\end{array}$ & $\begin{array}{c}240 \\
51\end{array}$ & $\begin{array}{c}1 \\
0.692\end{array}$ & $\begin{array}{c}\text { Referent } \\
0.372-1.287\end{array}$ \\
\hline Drunk & $\begin{array}{l}\text { Never } \\
\text { Sometime }\end{array}$ & $\begin{array}{c}291 \\
79\end{array}$ & $\begin{array}{c}1 \\
2.479\end{array}$ & $\begin{array}{c}\text { Referent } \\
0.203-30.336\end{array}$ & $\begin{array}{c}242 \\
52\end{array}$ & $\begin{array}{c}1 \\
0.334\end{array}$ & $\begin{array}{c}\text { Referent } \\
0.135-0.823\end{array}$ \\
\hline
\end{tabular}




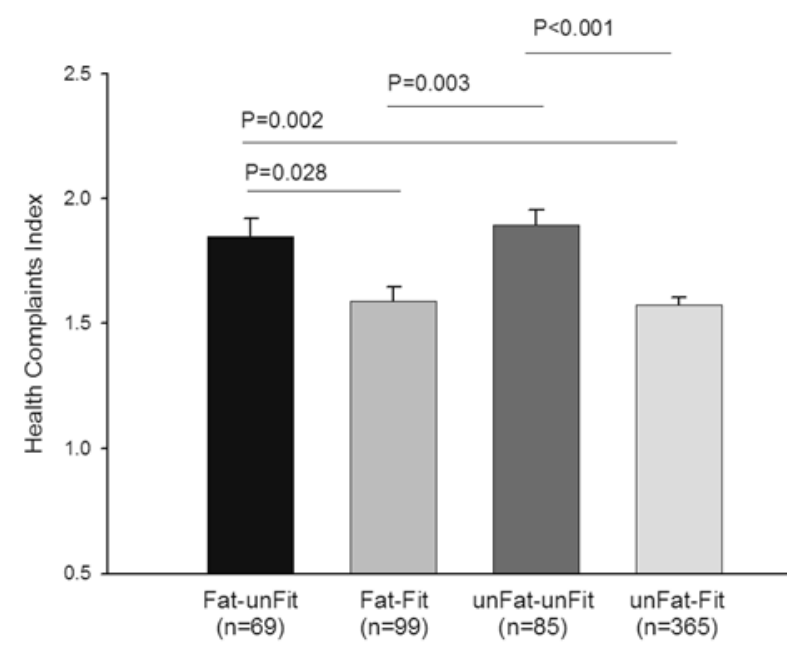

Figure 1 - Health complaints index by fat-fit categories. Values express mean and SEM.

FITNESSGRAM standards instead of BMI groups and results did not change (data not shown).

\section{Discussion}

The main finding of the current study is that cardiorespiratory fitness is negatively associated with health complaints in youth. In contrast, fatness is positively associated with health complaints index. Moreover, having a low cardiorespiratory fitness level increases the likelihood of having health complaints and risk behaviors such as drinking alcohol sometime. We also showed that fit youth had significantly lower values of health complaints index than their unfit counterparts regardless of their weight status.

\section{Cardiorespiratory Fitness and Health Complaints}

Only 2 studies examined the relationship between cardiorespiratory fitness and health complaints in youth, with contradictory results. Crews et al $^{9}$ observed that high levels of cardiorespiratory fitness were associated with lower depression, whereas no association was observed between fitness and anxiety. In contrast, Bonhauser et al ${ }^{10}$ observed that cardiorespiratory fitness was inversely associated with anxiety but not with depression. In our study, we computed a health complaints index ${ }^{14,42}$ because subjective health complaints such as headache, stomach-ache, backache, feeling low, irritability or bad temper, feeling nervous, difficulties getting to sleep, and feeling dizzy tend to occur in cluster rather than as single symptoms. ${ }^{43}$ We observed a negative association between cardiorespiratory fitness and health complaints index in both children and adolescents. In addition, our data showed that youth with low cardiorespiratory fitness had 2.5 higher likelihood of reporting health complaints sometime than their fit counterparts.

\section{Cardiorespiratory Fitness and Health Risk Behaviors}

We observed that cardiorespiratory fitness was inversely associated with smoking in adolescents, which is in line with prior studies. ${ }^{11-13}$ On the other hand we did not observe an association between cardiorespiratory fitness and alcohol use, which confirms the findings reported by Montoye et al. ${ }^{11}$ They showed, in a 16 to 20 years old group, that nondrinkers and the heaviest drinkers had the lowest cardiorespiratory fitness levels, whereas moderate drinkers had the highest cardiorespiratory fitness levels. We found that youth with low cardiorespiratory fitness were more likely of drinking sometime. Likewise, unfit adolescents had higher risk of getting drunk sometimes. From a public health perspective, this observation is particularly important given the negative consequences of drinking. Despite many studies have been conducted on alcohol ingestion and physical performance in adults, no consensus has been achieved. ${ }^{44}$

\section{Fatness and Health Complaints}

The association between overweight-obesity and psychological health symptoms (eg, depression) has been widely addressed in youth. ${ }^{17,18,45-48}$ In contrast, less is known regarding the association between overweight-obesity and psychosomatic symptoms (eg, health complaints). We observed that overweight-obese children or those with high body fat percentage had $\sim 2$ times higher risk of reporting health complaints than their normal weight peers. This finding is consistent with another study conducted in Palestinian adolescents. ${ }^{20}$ However, we did not observe an association between overweight-obesity and health complaints in adolescents. This findings might suggest that the association between overweight-obese and health complaints in childhood does not track into adolescence. Further longitudinal studies may also clarify these associations.

\section{Fatness and Health Risk Behaviors}

The association between weight status and smoking and alcohol remains unclear. ${ }^{17-19}$ We observed that overweight-obesity was positively associated with alcohol use in children but not in adolescents. Pasch et $\mathrm{al}^{18}$ found that joined alcohol, tobacco and other drug use in seventh grade predicted BMI in eighth grade, but not separated. Recently, Farhat et $\mathrm{al}^{49}$ showed that overweight and obesity was significantly associated with frequent smoking and drinking in adolescent girls but not in adolescent boys. These findings are alarming as the confluence of being overweight and drinking alcohol and smoking might have profound impact on youth' overall current and long-term health. Future studies are needed to clarify which role of potential confounding factors, such as peer and family relationship, socioeconomic status and parental education in the relationship of BMI with smoking and drinking. 


\section{Fatness-Fitness and Health Complaints}

We also analyzed the combined influence of fitness and fatness on health complaints. We observed that fit youth had significantly lower values of health complaints index than their unfit group counterparts (ie, fat-unfit and unfatunfit) regardless of the weight status. This indicates that high levels of cardiorespiratory fitness might overcome the deleterious effects of overweight-obesity. This finding is consistent with other studies that examined the combined influence of fitness and fatness on other health outcomes such as insulin resistance, ${ }^{50}$ blood pressure, ${ }^{51}$ and metabolic risk. ${ }^{7,52}$ This implies that interventions to prevent states of unfavorable health profiles should focus not only on weight reduction but also on enhancing cardiorespiratory fitness.

\section{Limitations of the Study}

A limitation of this study is its cross-sectional nature, which does not permit inferences about causality to any of the associated factors in the study. In addition, as health complaints index and health risk behaviors are based on self-report, it is possible that some study participants may have misreported either intentionally or inadvertently on any question asked. However, intentional misreporting was probably minimized by the fact that study participants completed the questionnaires anonymously, and the questions used in this study, belonging to HBSC questionnaire, are reliable and valid. ${ }^{31,32}$ It should also be recognized that the studied sample is not representative of the Spanish children and adolescent population; yet, our data are fully comparable with nationally representative data obtained from the AVENA study ${ }^{53,54}$ and the HBSC 2005/2006 survey. ${ }^{55}$ In addition, cardiorespiratory fitness and fatness were assessed by objective measures.

\section{Conclusions}

The current study suggests that cardiorespiratory fitness is inversely associated with health complaints index in youth. Having a low cardiorespiratory fitness level increases the risk of having health complaints and drinking sometime. It also shows that fatness is positively associated with health complaints, mainly in children. These findings suggest the need to increase cardiorespiratory fitness and prevent body weight and fat gain early during development. However, the deleterious consequences ascribed to overweight-obesity may be attenuated with high levels of cardiorespiratory fitness.

\section{Acknowledgments}

The study was funded by Centro Andaluz de Medicina del Deporte, Junta de Andalucía, Orden 4/02/05, BOJA n ${ }^{\circ} 37$ (Ref. JA-CTD2005-01), the Swedish Council for Working Life and Social Research (FAS) and the Spanish Ministry of Science and Innovation (RYC-2010-05957, RYC-2011-09011).

\section{References}

1. Garralda ME. A selective review of child psychiatric syndromes with a somatic presentation. Br J Psychiatry. 1992;161:759-773. PubMed doi:10.1192/bjp.161.6.759

2. Tellnes G, Svendsen KO, Bruusgaard D, Bjerkedal T. Incidence of sickness certification. Proposal for use as a health status indicator. Scand J Prim Health Care. 1989;7:111117. PubMed doi:10.3109/02813438909088657

3. Haugland S, Wold B, Stevenson J, Aaroe LE, Woynarowska B. Subjective health complaints in adolescence. A cross-national comparison of prevalence and dimensionality. Eur J Public Health. 2001;11:4-10. PubMed doi:10.1093/eurpub/11.1.4

4. Rehm J, Taylor B, Room R. Global burden of disease from alcohol, illicit drugs and tobacco. Drug Alcohol Rev. 2006;25:503-513. PubMed doi:10.1080/09595230600944453

5. Burke GL, Hunter SM, Croft JB, Cresanta JL, Berenson GS. The interaction of alcohol and tobacco use in adolescents and young adults: Bogalusa Heart Study. Addict Behav. 1988;13:387-393. PubMed doi:10.1016/03064603(88)90046-9

6. Ortega FB, Ruiz JR, Castillo MJ, Sjostrom M. Physical fitness in childhood and adolescence: a powerful marker of health. Int J Obes (Lond). 2008;32:1-11. PubMed doi:10.1038/sj.ijo.0803774

7. Mesa JL, Ruiz JR, Ortega FB, et al. Aerobic physical fitness in relation to blood lipids and fasting glycaemia in adolescents: influence of weight status. Nutr Metab Cardiovasc Dis. 2006;16:285-293. PubMed doi:10.1016/j. numecd.2006.02.003

8. Ruiz JR, Castro-Piñero J, Artero EG, et al. Predictive validity of health-related fitness in youth: a systematic review. Br J Sports Med. 2009;43:909-923. PubMed doi:10.1136/ bjsm.2008.056499

9. Crews DJ, Lochbaum MR, Landers DM. Aerobic physical activity effects on psychological well-being in low-income Hispanic children. Percept Mot Skills. 2004;98:319-324. PubMed doi:10.2466/pms.98.1.319-324

10. Bonhauser M, Fernandez G, Puschel K, et al. Improving physical fitness and emotional well-being in adolescents of low socioeconomic status in Chile: results of a schoolbased controlled trial. Health Promot Int. 2005;20:113122. PubMed doi:10.1093/heapro/dah603

11. Montoye HJ, Gayle R, Higgins M. Smoking habits, alcohol consumption and maximal oxygen uptake. Med Sci Sports Exerc. 1980;12:316-321. PubMed

12. Boreham C, Twisk J, van Mechelen W, Savage M, Strain J, Cran G. Relationships between the development of biological risk factors for coronary heart disease and lifestyle parameters during adolescence: The Northern Ireland Young Hearts Project. Public Health. 1999;113:7-12. PubMed

13. Bernaards CM, Twisk JW, Van Mechelen W, Snel J, Kemper HC. A longitudinal study on smoking in relationship to fitness and heart rate response. Med Sci Sports Exerc. 2003;35:793-800. PubMed doi:10.1249/01. MSS.0000064955.31005.E0

14. annotti RJ, Janssen I, Haug E, Kololo H, Annaheim B, Borraccino A. Interrelationships of adolescent physical activity, screen-based sedentary behaviour, and social and psychological health. Int J Public Health. 2009;54(Suppl 2):191-198. PubMed doi:10.1007/s00038-009-5410-z

15. Iannotti RJ, Kogan MD, Janssen I, Boyce WF. Patterns of adolescent physical activity, screen-based media use, and positive and negative health indicators in the U.S. and 
Canada. J Adolesc Health. 2009;44:493-499. PubMed doi:10.1016/j.jadohealth.2008.10.142

16. Tercedor P, Martín-Matillas M, Chillón P, et al. Incremento del consumo de tabaco y disminución del nivel de práctica de actividad física en adolescentes españoles. Estudio AVENA. Nutr Hosp. 2007;22:119-136.

17. Fonseca H, Matos MG, Guerra A, Pedro JG. Are overweight and obese adolescents different from their peers? Int J Pediatr Obes. 2009;4:166-174. PubMed doi:10.1080/17477160802464495

18. Pasch KE, Nelson MC, Lytle LA, Moe SG, Perry CL. Adoption of risk-related factors through early adolescence: associations with weight status and implications for causal mechanisms. J Adolesc Health. 2008;43:387-393. PubMed doi:10.1016/j.jadohealth.2008.02.009

19. Potter BK, Pederson LL, Chan SS, Aubut JA, Koval JJ. Does a relationship exist between body weight, concerns about weight, and smoking among adolescents? An integration of the literature with an emphasis on gender. Nicotine Tob Res. 2004;6:397-425. PubMed doi:10.1080 /14622200410001696529

20. Al Sabbah H, Vereecken C, Abdeen Z, Coats E, Maes L. Associations of overweight and of weight dissatisfaction among Palestinian adolescents: findings from the national study of Palestinian schoolchildren (HBSC-WBG2004). J Hum Nutr Diet. 2009;22:40-49. PubMed doi:10.1111/ j.1365-277X.2008.00901.x

21. Fonseca H, Matos MG, Guerra A, Pedro JG. Are overweight adolescents at higher risk of engaging in unhealthy weight-control behaviours? Acta Paediatr. 2009;98:847852. PubMed doi:10.1111/j.1651-2227.2009.01244.x

22. Swallen KC, Reither EN, Haas SA, Meier AM. Overweight, obesity, and health-related quality of life among adolescents: the National Longitudinal Study of Adolescent Health. Pediatrics. 2005;115:340-347. PubMed doi:10.1542/peds.2004-0678

23. Padilla-Moledo C, Castro-Pinero J, Ortega F, et al. Psychological positive health, cardiorespiratory fitness and fatness in children and adolescents. Eur J Public Health. 2012;22:52-56. PubMed

24. Brener ND, Collins JL. Co-occurrence of health-risk behaviors among adolescents in the United States. $J$ Adolesc Health. 1998;22:209-213. PubMed doi:10.1016/ S1054-139X(97)00161-4

25. DuRant RH, Smith JA, Kreiter SR, Krowchuk DP. The relationship between early age of onset of initial substance use and engaging in multiple health risk behaviors among young adolescents. Arch Pediatr Adolesc Med. 1999;153:286-291. PubMed

26. Kulbok PA, Cox CL. Dimensions of adolescent health behavior. J Adolesc Health. 2002;31:394-400. PubMed doi:10.1016/S1054-139X(02)00422-6

27. Neumark-Sztainer D, Story M, French S, Cassuto N, Jacobs DR, Jr, Resnick MD. Patterns of health-compromising behaviors among Minnesota adolescents: sociodemographic variations. Am J Public Health. 1996;86:1599_ 1606. PubMed doi:10.2105/AJPH.86.11.1599

28. Weden MM, Zabin LS. Gender and ethnic differences in the co-occurrence of adolescent risk behaviors. Ethn Health. 2005;10:213-234. PubMed doi:10.1080/13557850500115744

29. Balaguer I. Estilos de vida de la adolescencia. Valencia: Promolibro; 2002.

30. Wold B. Health-behavior in schoolchildren: a WHO crossnational survey. Resource package questions 1993-94. Bergen: University of Berguen; 1995.
31. Roberts C, Freeman J, Samdal O, et al. The Health Behaviour in School-aged Children (HBSC) study: methodological developments and current tensions. Int J Public Health. 2009;54(Suppl 2):140-150. PubMed doi:10.1007/ s00038-009-5405-9

32. Booth ML, Okely AD, Chey T, Bauman A. The reliability and validity of the physical activity questions in the WHO health behaviour in schoolchildren (HBSC) survey: a population study. Br J Sports Med. 2001;35:263-267. PubMed doi:10.1136/bjsm.35.4.263

33. Leger LA, Mercier D, Gadoury C, Lambert J. The multistage 20 metre shuttle run test for aerobic fitness. J Sports Sci. 1988;6:93-101. PubMed doi:10.1080/02640418808729800

34. Cooper Institute for Aerobics Research. The prudential Fitnessgram: test administration manual. 3rd ed. Champaign, IL: Human Kinetics; 2004.

35. Cole TJ, Bellizzi MC, Flegal KM, Dietz WH. Establishing a standard definition for child overweight and obesity worldwide: international survey. BMJ. 2000;320:12401243. PubMed doi:10.1136/bmj.320.7244.1240

36. Slaughter MH, Lohman TG, Boileau RA, et al. Skinfold equations for estimation of body fatness in children and youth. Hum Biol. 1988;60:709-723. PubMed

37. Strauss RS, Knight J. Influence of the home environment on the development of obesity in children. Pediatrics. 1999;103:e85. PubMed doi:10.1542/peds.103.6.e85

38. Mendelson BK, White DR, Schliecker E. Adolescents' weight, sex, and family functioning. Int J Eat Disord. 1995;17:73-79. PubMed doi:10.1002/1098-108X(199501)17:1<73::AIDEAT2260170110>3.0.CO;2-1

39. Roberts CK, Freed B, McCarthy WJ. Low aerobic fitness and obesity are associated with lower standardized test scores in children. J Pediatr. 2010;156:711-718.

40. Ruiz JR, Ortega FB, Castillo R, et al. Physical activity, fitness, weight status, and cognitive performance in adolescents. J Pediatr. 2010;157(6):917-922. PubMed

41. Castro-Pinero J, Artero EG, Espana-Romero V, et al. Criterion-related validity of field-based fitness tests in youth: a systematic review. Br J Sports Med. 2010;44:934-943. PubMed doi:10.1136/bjsm.2009.058321

42. Moreno C, Sanchez-Queija I, Munoz-Tinoco V, et al. Cross-national associations between parent and peer communication and psychological complaints. Int J Public Health. 2009;54(Suppl 2):235-242. PubMed doi:10.1007/ s00038-009-5415-7

43. Garralda ME. Somatisation in children. J Child Psychol Psychiatry. 1996;37:13-33. PubMed doi:10.1111/j.1469-7610.1996.tb01378.x

44. Ferreira SE, de Mello MT, Rossi MV, Souza-Formigoni ML. Does an energy drink modify the effects of alcohol in a maximal effort test? Alcohol Clin Exp Res. 2004;28:14081412. PubMed doi:10.1097/01.ALC.0000139822.74414. EC

45. Daniels SR, Arnett DK, Eckel RH, et al. Overweight in children and adolescents: pathophysiology, consequences, prevention, and treatment. Circulation. 2005;111:19992012. PubMed doi:10.1161/01.CIR.0000161369.71722.10

46. Goodman E, Whitaker RC. A prospective study of the role of depression in the development and persistence of adolescent obesity. Pediatrics. 2002;110:497-504. PubMed doi:10.1542/peds.110.3.497

47. Crow S, Eisenberg ME, Story M, Neumark-Sztainer D. Psychosocial and behavioral correlates of dieting among 
overweight and non-overweight adolescents. $J$ Adolesc Health. 2006;38:569-574. PubMed doi:10.1016/j.jadohealth.2005.05.019

48. Erermis S, Cetin N, Tamar M, Bukusoglu N, Akdeniz F, Goksen D. Is obesity a risk factor for psychopathology among adolescents? Pediatr Int. 2004;46:296-301. PubMed doi:10.1111/j.1442-200x.2004.01882.x

49. Farhat T, Iannotti RJ, Simons-Morton BG. Overweight, obesity, youth, and health-risk behaviors. Am J Prev Med. 2010;38:258-267. PubMed doi:10.1016/j. amepre.2009.10.038

50. Ruiz JR, Rizzo NS, Ortega FB, Loit HM, Veidebaum T, Sjostrom M. Markers of insulin resistance are associated with fatness and fitness in school-aged children: the European Youth Heart Study. Diabetologia. 2007;50:14011408. PubMed doi:10.1007/s00125-007-0678-0

51. Ruiz JR, Ortega FB, Loit HM, Veidebaum T, Sjostrom M. Body fat is associated with blood pressure in school-aged girls with low cardiorespiratory fitness: The European
Youth Heart Study. J Hypertens. 2007;25:2027-2034. PubMed doi:10.1097/HJH.0b013e328277597f

52. Eisenmann JC, Welk GJ, Ihmels M, Dollman J. Fatness, fitness, and cardiovascular disease risk factors in children and adolescents. Med Sci Sports Exerc. 2007;39:1251-1256. PubMed doi:10.1249/MSS.0b013e318064c8b0

53. Moreno LA, Mesana MI, Fleta J, et al. Overweight, obesity and body fat composition in spanish adolescents. The AVENA Study. Ann Nutr Metab. 2005;49:71-76. PubMed doi:10.1159/000084738

54. Ortega FB, Ruiz JR, Castillo MJ, et al. [Low level of physical fitness in Spanish adolescents. Relevance for future cardiovascular health (AVENA study)] Rev Esp Cardiol. 2005;58:898-909. PubMed doi:10.1157/13078126

55. Moreno C, Muñoz-Tinoco V, Pérez P, et al. Desarrollo adolescente y salud. Resultados del Estudio HBSC-2006 con chicos y chicas españoles de 11 a 17 años. Madird: Ministerio de Sanidad y Consumo; 2008. 
Copyright of Journal of Physical Activity \& Health is the property of Human Kinetics Publishers, Inc. and its content may not be copied or emailed to multiple sites or posted to a listserv without the copyright holder's express written permission. However, users may print, download, or email articles for individual use. 